Article

\title{
The Potassium-Induced Decomposition Pathway of HCOOH on Rh(111)
}

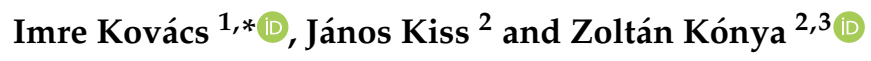 \\ 1 Institute of Technology, University of Dunaújváros, Táncsics M. u. 1/A, 2401 Dunaújváros, Hungary \\ 2 MTA-SZTE Reaction Kinetics and Surface Chemistry Research Group, University of Szeged, Rerrich Béla \\ Square 1, 6720 Szeged, Hungary; jkiss@chem.u-szeged.hu (J.K.); konya@chem.u-szeged.hu (Z.K.) \\ 3 Department of Applied and Environmental Chemistry, University of Szeged, Interdisciplinary Excellence \\ Centre, Rerrich Béla Squer 1, H-6720 Szeged, Hungary \\ * Correspondence: kovacsimidr@gmail.com
}

Received: 28 May 2020; Accepted: 13 June 2020; Published: 16 June 2020

check for updates

\begin{abstract}
Formic acid (FA) can be considered both a $\mathrm{CO}$ and a $\mathrm{H}_{2}$ carrier via selective dehydration and dehydrogenation pathways, respectively. The two processes can be influenced by the modification of the active components of the catalysts used. In the present study the adsorption of FA and the decomposition of the formed formate intermediate were investigated on potassium promoted $\mathrm{Rh}(111)$ surfaces. The preadsorbed potassium markedly increased the uptake of FA at $300 \mathrm{~K}$, and influenced the decomposition of formate depending on the potassium coverage. The work function $(\Delta \phi)$ is increased by the adsorption of FA on $\mathrm{K} / \mathrm{Rh}(111)$ at $300 \mathrm{~K}$ suggesting a large negative charge on the chemisorbed molecule, which could be probably due to the enhanced back-donation of electrons from the K-promoted Rh into an empty $\pi$ orbital of $\mathrm{HCOOH}$. The binding energy of the formate species is therefore increased resulting in a greater concentration of irreversibly adsorbed formate species. Decomposition of the formate species led to the formation of $\mathrm{H}_{2}, \mathrm{CO}_{2}, \mathrm{H}_{2} \mathrm{O}$, and $\mathrm{CO}$, which desorbed at significantly higher temperatures from the K-promoted surface than from the K-free one as it was proven by thermal desorption studies. Transformation of surface formate to carbonate (evidenced by UPS) and its decomposition and desorption is responsible for the high temperature CO and $\mathrm{CO}_{2}$ formation.
\end{abstract}

Keywords: formic acid decomposition; formate intermediate; potassium adatom; Rh surfaces

\section{Introduction}

Formic acid (FA), $\mathrm{HCOOH}$, is an important chemical for the renewable energy system. FA can be decomposed to $\mathrm{CO}$ and $\mathrm{H}_{2} \mathrm{O}$ by dehydration or to $\mathrm{H}_{2}$ and $\mathrm{CO}_{2}$ by dehydrogenation. A third way gives green syngas by competitive decomposition [1-3]:

$$
\begin{gathered}
\mathrm{HCOOH}=\mathrm{CO}+\mathrm{H}_{2} \mathrm{O} \\
\mathrm{HCOOH}=\mathrm{CO}_{2}+\mathrm{H}_{2} \\
\mathrm{HCOOH}=\mathrm{CO}+\mathrm{H}_{2}+\mathrm{O}
\end{gathered}
$$

The selective decomposition path of FA offers promising channels either for high purity CO, which is widely used in semiconductor industry [4] or for $\mathrm{H}_{2}$ in high purity, which can be applied for fuel cell vehicles; FA is a good candidate as a $\mathrm{H}_{2}$ storage compound [5-8]. The importance of FA for fuel cell application can be demonstrated nowadays by an increased number of patents. In addition, the FA decomposition can provide syngas with different $\mathrm{CO} / \mathrm{H}_{2}$ ratio for chemical synthesis 
or applications [1]. FA can be synthetized by either the catalytic $\mathrm{CO}_{2}$ hydrogenation $[9,10]$ or the oxidation of biomass [11,12]. It was found that alkali cation $\left(\mathrm{Na}^{+}\right)$near to Rh particles promote the conversion of $\mathrm{CO}_{2}$ towards $\mathrm{HCOOH}$ production via formation of formate. The formate species and the hydride rhodium complexes are considered reaction intermediates in formic acid formation [10].

Formic acid, $\mathrm{HCOOH}$, is a very useful precursor molecule in producing formate surface intermediate because it can be dehydrogenated on metal and oxide surfaces. The knowledge of the surface chemistry of adsorbed formate as a reaction intermediate is of great assistance in the elaboration of the mechanism of several important catalytic reactions which contain $C_{1}$ species [13] such as water -gas shift reaction [14,15], methanol synthesis [16-20] and methanation of $C O$ [21,22] and $\mathrm{CO}_{2}$ [23-34]. The formate species can be detected on supported metal catalysts during these reactions mainly with IR vibrational techniques. The IR spectra obtained after the adsorption of $\mathrm{HCOOH}$ were the same on supported metal $(\mathrm{Rh})$ and on the support alone. It was suggested that formate ion formed in the above mentioned reactions, on metal sites, then it is re-located on the support, or the support basically influence the stability of the formate species on metals. Therefore, it is desirable to investigate its formation and stability on clean metal surfaces under UHV conditions without the disturbing effect of the support. For this purpose, the surface study of the dissociative adsorption of FA is an excellent topic.

It turns out from several studies that not only the support, but also the different additives have a marked influence on the decomposition of FA and the characteristics of the surface formate on different metal surfaces [35-42]. On rhodium surfaces, the attention is focused on the effect of electronegative (preadsorbed oxygen) and electropositive (potassium) additives. The interaction of formic acid with clean and oxygen-covered $\mathrm{Rh}(111)$ surfaces has been investigated by electron energy loss (in the electronic range), thermal desorption and photoelectron spectroscopy [43]. The formate species on clean $\mathrm{Rh}(111)$ was stable up to $200 \mathrm{~K}$, but decomposed completely at 200-250 K. The major products were: $\mathrm{H}_{2}$ and $\mathrm{CO}_{2}$, but $\mathrm{H}_{2} \mathrm{O}$ and $\mathrm{CO}$ were also formed. Preadsorbed oxygen exerted a readily observable influence on the interaction of $\mathrm{HCOOH}$ with the $\mathrm{Rh}(111)$ surface. It increased the extent of dissociation of FA and extended the region of stability of surface formate by at least $80-100 \mathrm{~K}$. This was demonstrated by the higher stability of photoemission peaks of formate and by the simultaneous production of $\mathrm{CO}_{2}$ and $\mathrm{H}_{2} \mathrm{O}$ with $\mathrm{T}_{\mathrm{p}}=377-385 \mathrm{~K}$ at saturation oxygen coverage. $\mathrm{CO}$ production was not observed. The effect of boron contamination on the $\mathrm{Rh}$ foil is different, in this case the boron segregating from the bulk interacts with the products $\left(\mathrm{H}_{2} \mathrm{O}, \mathrm{CO}_{2}\right)$, therefore it increases the amount of $\mathrm{CO}$ and $\mathrm{H}_{2}$ [44-46].

The effect of an electropositive potassium additive on the decomposition of $\mathrm{HCOOH}$ on $\mathrm{Rh}(111)$ was studied previously $[47,48]$. The photoelectron [UPS] and thermal desorption spectroscopic study was restricted only to the low temperature region (adsorption temperature was $100 \mathrm{~K}$ ). The preadsorbed potassium promoted the dissociation of FA and increased the surface concentration of the most stable formate anion. In the light of the obtained results, it is desirable to investigate the interaction between the potassium and the formate at high temperatures, and also at different potassium and FA coverages on $\mathrm{Rh}(111)$. In the present study ultraviolet photoelectron spectroscopy (UPS), work function $(\Delta \phi)$ and thermal desorption spectroscopy (TDS) studies were carried out.

\section{Results}

\subsection{Thermal Desorption Measurements}

In the first series of measurements, we investigated the effects of the potassium coverage on the desorption of $\mathrm{HCOOH}$, and on the formation of the decomposition products. Molecular FA desorption was not observed after adsorption at $300 \mathrm{~K}$ on clean $\mathrm{Rh}(111)$. CO formation was detected with $\mathrm{T}_{\mathrm{p}}=489 \mathrm{~K}$ (Figure 1A). $\mathrm{H}_{2}$ appeared on TPD spectra with a weak, broad peak between $320-350 \mathrm{~K}$. $\mathrm{CO}_{2}$ and $\mathrm{H}_{2} \mathrm{O}$ as decomposition products were not observed after adsorption at $300 \mathrm{~K}$. When these products are formed, they leave the surface immediately the clean surface. In our previous work, 
where the adsorption temperature was $100 \mathrm{~K}$, all $\mathrm{CO}_{2}$ and $\mathrm{H}_{2} \mathrm{O}$ desorbed below $300 \mathrm{~K}$. The transient surface intermediate was the formate species [43].

The effect of potassium coverage $\left(\Theta_{\mathrm{K}}\right)$ on the adsorption of FA at $300 \mathrm{~K}$ was investigated between $\sim 0.1$ and 0.36 coverages. At $\Theta_{\mathrm{K}}=0.36$ the potassium reaches the saturation coverage (1 ML) [49]. The presence of potassium, with different coverages, altered the bonding mode of FA and the formation temperature of the products. Both the work function changes $(\Delta \phi)$ and the core level peak shift (XPS) support the notation of a considerable charge transfer from $\mathrm{K}$ to $\mathrm{Rh}$ at low coverages, and a gradual neutralization at saturation [49-54]. At $\Theta_{\mathrm{K}}<0.15$ the potassium is positively charged $\left(\mathrm{K}^{+}\right)$, while at $\Theta_{\mathrm{K}}=0.36$ the potassium exhibits mainly metallic character.
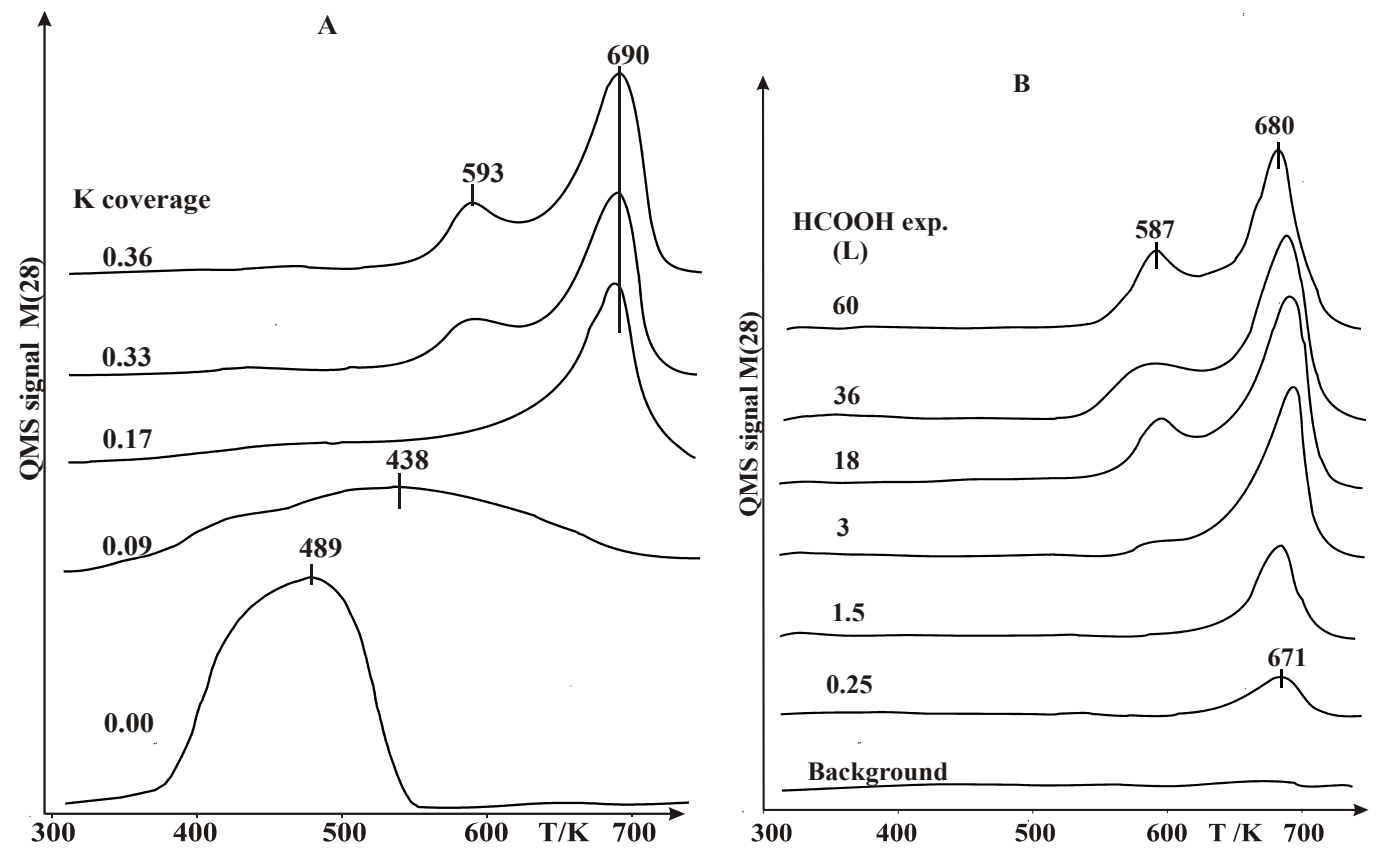

Figure 1. (A) Thermal desorption spectra of CO from different potassium covered $\mathrm{Rh}(111)$ FA exposure was $12 \mathrm{~L}$. (B) Thermal desorption spectra of $\mathrm{CO}$ as a function of $\mathrm{HCOOH}$ exposure at monolayer $\mathrm{K}$ coverage $\left(\Theta_{\mathrm{K}}=0.3\right)$.

Figure 1A shows the TD spectra of $\mathrm{CO}$ after adsorption of FA at different potassium coverages. At $\Theta_{K}=0.09$, where the potassium exhibits ionic character, a very broad feature was detected. At a higher $\mathrm{K}$ concentration the potassium acquires a metallic-like character, and the $\mathrm{CO}$ desorption temperature shifted to 593 and $690 \mathrm{~K}$. Detailed $\mathrm{CO}$ desorption spectra are displayed at $\Theta_{\mathrm{K}}=0.36$ as a function of FA exposures on Figure 1B. Very similar desorption features were detected after $\mathrm{CO}$ was adsorbed on potassium-dosed $\mathrm{Rh}(111)$ [55-57]. The results indicate both strengthening of the M-C bond and the weakening of the $\mathrm{C}-\mathrm{O}$ bond in the presence of potassium, due presumably to an increased electron occupancy of the $2 \pi^{*}$-orbital of $\mathrm{CO}$. Broadening and asymmetry of the vibrational peaks suggest that the proximity of the $\mathrm{CO}$ molecules to the potassium adatoms influence the chemisorption behavior, although nonlocal interactions are also indicated. Hydrogen desorbs independently of the potassium coverage at $T_{p}=345 \mathrm{~K}$ (Figure $2 \mathrm{~A}$ ), at high exposures a tailing can be seen at the high temperature side $(\sim 450 \mathrm{~K})$. As follows from the results plotted in Figure $2 \mathrm{~B}$, the desorption of $\mathrm{H}_{2} \mathrm{O}$ occurred in new high temperature states $(\mathrm{Tp}=440$ and $500-600 \mathrm{~K})$ from $\mathrm{K}$ covered $\mathrm{Rh}(111)$ These states could be associated with the potassium stabilized water desorption and adsorbed $\mathrm{OH}$ recombination especially at around monolayer potassium coverage. Strong interaction between $\mathrm{K}$ and water including dissociation was established previously, and a strong thermodynamic driving force to $\mathrm{KOH}$ formation $\left(\Delta \mathrm{H}_{\mathrm{f}(\mathrm{KOH})}=-424.7 \mathrm{~kJ} / \mathrm{mol}\right)$ was calculated [57]. The amount of $\mathrm{H}_{2} \mathrm{O}$ formed during desorption significantly increased with potassium coverages at the same FA exposure. 

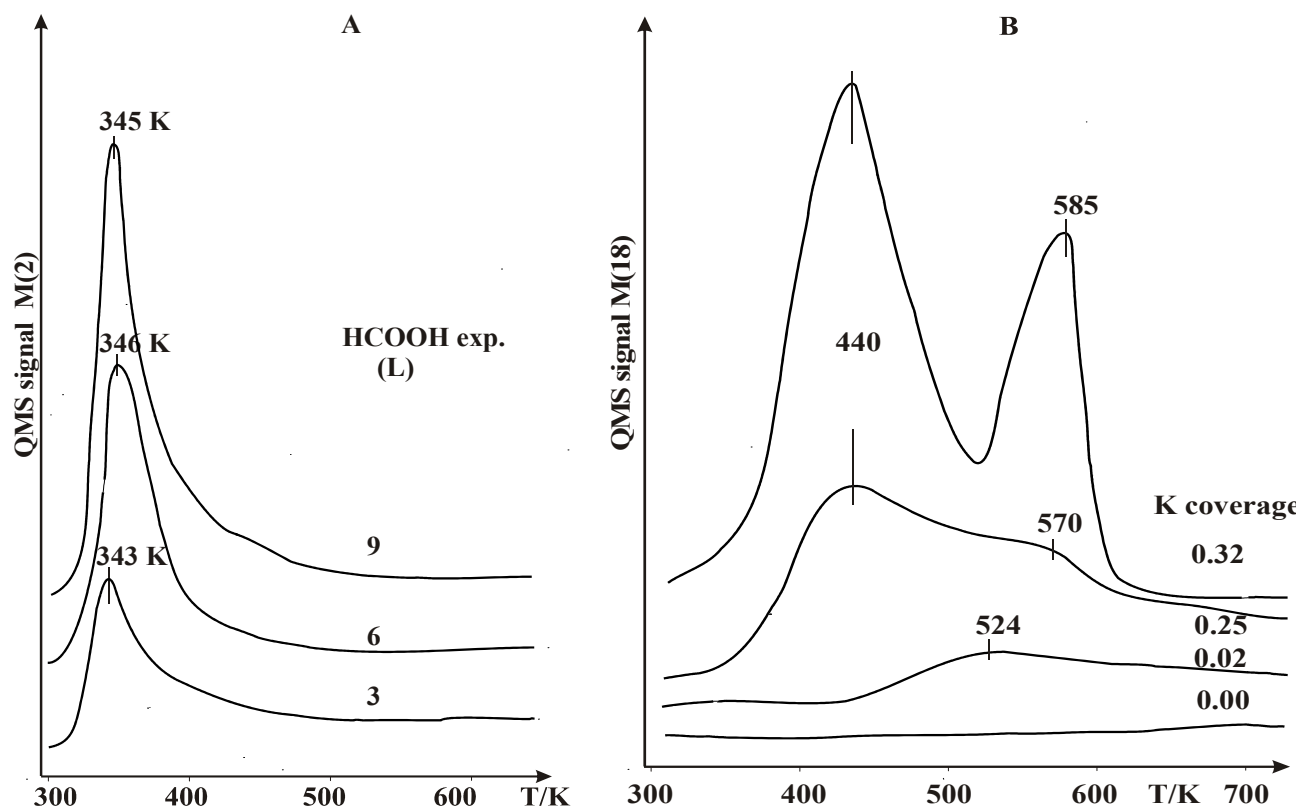

Figure 2. (A) Thermal desorption spectra of $\mathrm{H}_{2}$ from monolayer potassium coverage, $\left(\Theta_{\mathrm{K}}=0.3\right)$. (B) Thermal desorption spectra of $\mathrm{H}_{2} \mathrm{O}$ from different potassium covered $\mathrm{Rh}(111)$.

The $\mathrm{CO}_{2}$ TD spectra, after adsorption of FA at $300 \mathrm{~K}$, are more complex, due to the desorption and different steps of decomposition of surface complexes. Significant differences can be seen at different potassium coverages. TDS for $\mathrm{CO}_{2}$ at $\Theta_{\mathrm{K}}=0.1$ are displayed in Figure 3A.
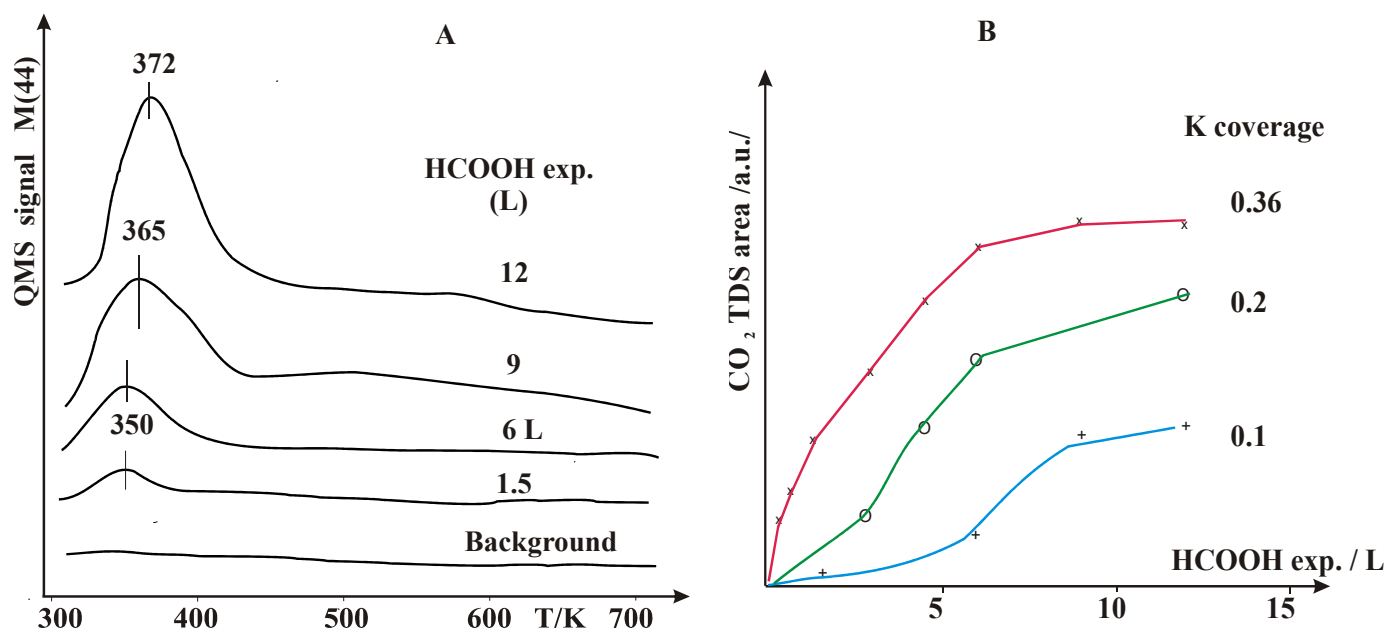

Figure 3. (A) Thermal desorption spectra of $\mathrm{CO}_{2}$ from low potassium coverage, $\left(\Theta_{\mathrm{K}}=0.1\right)$. (B) The amount of desorbed $\mathrm{CO}_{2}$ as a function of potassium coverage after different $\mathrm{HCOOH}$ exposures at $300 \mathrm{~K}$.

One dominant peak was detected; its peak temperature shifted from $350 \mathrm{~K}$ to $372 \mathrm{~K}$ with increasing $\mathrm{HCOOH}$ exposure. Very probably, the potassium stabilized the formate species via an electronic interaction [37-40], and then the stabilized formate decomposes at this temperature giving $\mathrm{CO}_{2}$ and $\mathrm{H}_{2}$. As the potassium coverage was increased the stabilization effect to formate also increased, very probably surface compounds are formed. The amount of $\mathrm{CO}_{2}$ formed during desorption significantly increased with the potassium coverage. The areas of the desorption peaks are plotted as a function of FA exposures at different potassium coverages in Figure 3B. The effect of potassium was exhibited in the higher desorption temperatures of decomposition products. The TD spectra obtained at $\Theta_{\mathrm{K}}=0.2$ shows an additional high temperature desorption peak; the first two peaks developed at 672 and 
$705 \mathrm{~K}$. When the FA exposure was increased to $6 \mathrm{~L}$, a weak peak appeared at $\mathrm{T}_{\mathrm{p}}=466 \mathrm{~K}$, and an intense one developed at $581 \mathrm{~K}$ (Figure $4 \mathrm{~A}$ ). The TD spectra of $\mathrm{CO}_{2}$ as a function of FA exposures at monolayer potassium coverage $\left(\Theta_{\mathrm{K}}=0.3\right)$, at which the potassium has a metallic character, are displayed in Figure 4B. At low FA exposures, $0.3-0.6 \mathrm{~L}$, two high temperature peaks with $\mathrm{T}_{\mathrm{p}}=654 \mathrm{~K}$ and $\mathrm{T}_{\mathrm{p}}=675 \mathrm{~K}$ were developed. From $3 \mathrm{~L}$ exposure, the intensity of these peaks increased, and a third peak was developed at $\mathrm{T}_{\mathrm{p}}=589 \mathrm{~K}$. It is important to mention again that $\mathrm{CO}$ desorption happened also at $\mathrm{T}_{\mathrm{p}}=587 \mathrm{~K}$ and $\mathrm{T}_{\mathrm{p}}=680 \mathrm{~K}$. These coinciding temperatures in the $\mathrm{CO}$ and $\mathrm{CO}_{2}$ desorption strongly suggest the same source of products. It should be emphasized that potassium stabilization also occurs in the co-adsorbed layer, in this potassium desorption was detected at $\mathrm{T}_{\mathrm{p}}=587 \mathrm{~K}$ and $\mathrm{T}_{\mathrm{p}}=680 \mathrm{~K}$ [49]. Similar coincidence temperatures were observed after $\mathrm{CO}_{2}$ adsorption from $\mathrm{K} / \mathrm{Rh}[49,58]$ and $\mathrm{K} / \mathrm{Pd}$ surfaces [59].
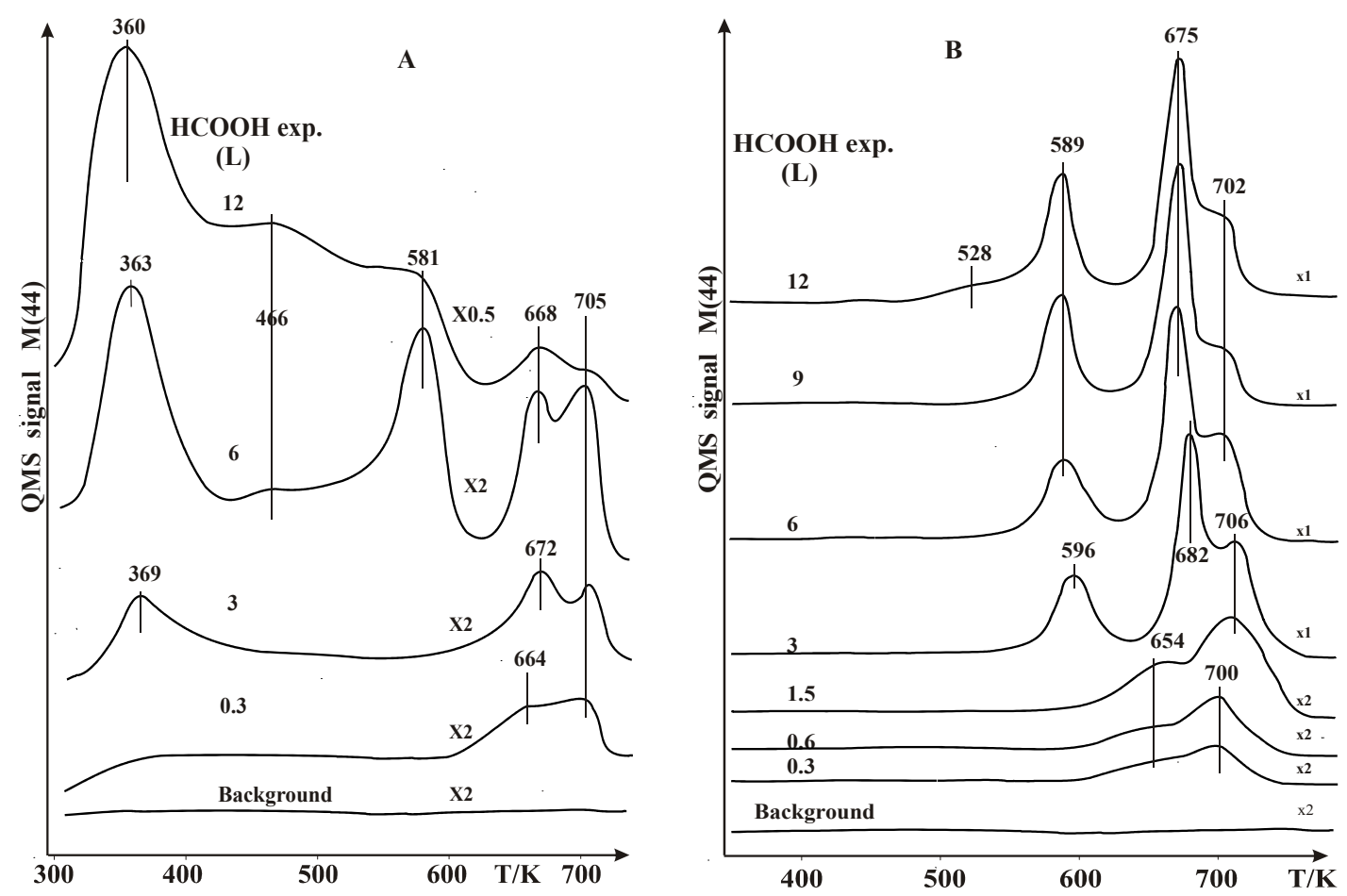

Figure 4. (A) Thermal desorption spectra of $\mathrm{CO}_{2}$ at $\Theta_{\mathrm{K}}=0.2$. (B) $\mathrm{CO}_{2}$ desorption spectra at monolayer $\mathrm{K}$ coverage, $\left(\Theta_{\mathrm{K}}=0.3\right)$ as a function of $\mathrm{HCOOH}$ exposure.

\subsection{Work Function $(\Delta \phi)$ and UPS Measurements}

In order to help understand the mechanism of the surface reactions in the co-adsorbed layer, work function and photo electron spectroscopic measurements (UPS) were carried out. The work function changes observed following potassium deposition on a clean $\mathrm{Rh}(111)$ surface were reported previously [49]. The work function of Rh decreased linearly with $\mathrm{K}$ exposure up to $\Theta_{\mathrm{K}} \sim 0.15$, $(\Delta \phi=-3.5 \mathrm{eV})$. Further $\mathrm{K}$ deposition led to a slight increase $(0.5 \mathrm{eV})$ in $(\Delta \phi)$. The large linear decrease in the work function at low potassium coverages indicates the formation of a species with high dipole moment; the formation of an ionic $\mathrm{K}$. Above $\Theta_{\mathrm{K}}=0.15$, a strong dipole-dipole depolarization starts to compensate the effect of the increasing K concentration, (formation of metallic potassium). Independently of the potassium coverage the adsorption of FA at $300 \mathrm{~K}$ resulted in work function increases (Figure 5A). The extent of increase is proportional with the $\mathrm{K}$ coverage. Heating of the coadsorbed layer resulted in a complex picture (Figure 5B). A decrease in the work function corresponds to the desorption and decomposition of adsorbed $\mathrm{HCOOH}$ species. Above $600 \mathrm{~K}$ the work function started to increase slowly. The original value for the clean Rh surface was attained only above $900-1000 \mathrm{~K}$. 


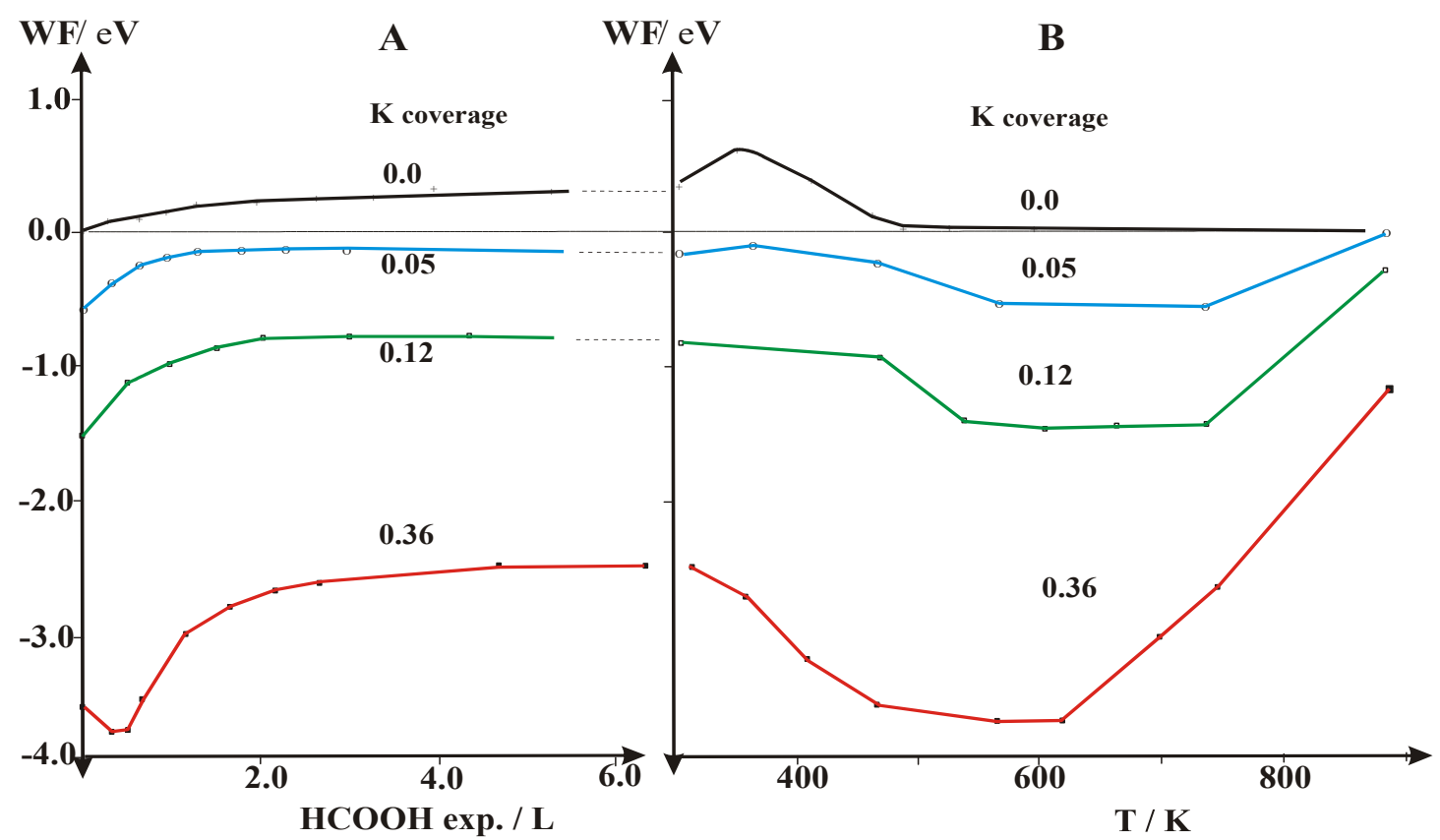

Figure 5. (A) Change of the work function, $(\Delta \phi)$, at different potassium coverage with FA exposure. (B) Change the work function during heating the adsorbed layer.

The photoemission spectra of adsorbed $\mathrm{HCOOH}$ were taken on a clean and K-dosed $\mathrm{Rh}(111)$ surface at $\Theta_{\mathrm{K}}=0.3$. The observed photoemissions obtained after $\mathrm{HCOOH}$ adsorption are collected in Table 1. Figure 6 shows the HeII UP spectra obtained on clean surface at different FA exposures. FA adsorption at $300 \mathrm{~K}$ resulted in two photoemission peaks at 8.2 and $11.5 \mathrm{eV}$, which correspond to the $5 \sigma / 1 \pi$ and $4 \delta$ orbitals of $C O$, respectively. These orbitals can be detected also after $\mathrm{CO}$ adsorption on a clean surface $[55,56]$. Their intensities remained constant up to $395 \mathrm{~K}$, then they decreased and disappeared around 510 K. Photoemissions attributable to formate at 5.3, 8.6, 10.2 and $14.2 \mathrm{eV}[43,60,61]$ were not observed. This result supports the hypothesis that the formate is not a stable intermediate above $300 \mathrm{~K}$ on a clean surface.

Table 1. Binding energies (in $\mathrm{eV}$ ) of adsorbates observed following $\mathrm{HCOOH}$ on $\mathrm{Rh}(111)$ and $\mathrm{K} / \mathrm{Rh}(111)$.

\begin{tabular}{cccc}
\hline & $\theta_{\mathbf{K}}$ & UPS & References \\
\hline $\mathrm{HCOOH}$ & 0 & 6.28 .910 .511 .9 & {$[43]$} \\
only at 100K & 0.1 & 6.29 .110 .512 .0 & {$[48]$} \\
& 0.33 & 6.29 .110 .512 .0 & {$[48]$} \\
$\mathrm{HCOO}^{-}$ & 0 & 5.38 .910 .213 .2 & {$[43,60,61]$} \\
& 0.1 & 5.28 .910 .214 .2 & {$[48]$} \\
$\mathrm{CO}_{3}{ }^{2-}$ & 0.33 & 5.28 .910 .314 .0 & {$[48]$, this work } \\
& 0.33 & 8.410 .2 & {$[48,62]$ this work } \\
$\mathrm{CO}$ & 0 & 8.010 .8 & {$[55,56]$} \\
& 0.1 & 8.010 .9 & {$[48]$} \\
$\mathrm{O}$ & 0.33 & 9.011 .5 & {$[48,51]$, this work } \\
& 0 & $\sim 67]$ \\
& 0.33 & 5.2 & {$[56,57]$, this work } \\
\hline
\end{tabular}

UPS after FA adsorption at $300 \mathrm{~K}$ and subsequent heating are presented in Figure 7 . When the FA was introduced to the potassium-covered $\mathrm{Rh}(111)$ at $\Theta_{\mathrm{K}}=0.3$, which corresponds to monolayer coverage, the ultraviolet spectrum was complex at $300 \mathrm{~K}$ (Figure 7). On this potassium-covered surface peaks were found at $5.4,8.9,10.3,14.2 \mathrm{eV}$, which correspond, to the $6 \mathrm{a}_{1}, 4 \mathrm{~b}_{2}, 5 \mathrm{a}_{1}$ and $4 \mathrm{a}_{1}$ orbitals of formate, respectively $[43,60,61]$. Above $420 \mathrm{~K}$ this adsorption form cannot be detected above $507 \mathrm{~K}$. The strong peaks are due to adsorbed $\mathrm{CO}$ found up to $705 \mathrm{~K}$ at 8.1 and $11.5 \mathrm{eV}$, which are characteristic 
of adsorbed CO on potassium-covered $\mathrm{Rh}(111)[48,51,56]$. From $507 \mathrm{~K}$ shoulders are visible at $\sim 8.4$ and $10.3 \mathrm{eV}$. These emissions can be attributed to surface carbonate and are detectable up to $640 \mathrm{~K}$. The weak feature could be due either to the low concentration of this surface compound or to the strong overlapping of the $\mathrm{CO} 5 \sigma / 1 \pi$ orbital with the unresolved combination of $3 \mathrm{e}^{\prime} / 1 \mathrm{a}^{\prime \prime}$ molecular orbitals of the $\mathrm{CO}_{3}$ species at $8.4 \mathrm{eV}$. The observed photoemission peaks conform well to those obtained for other carbonate species ( $3 \mathrm{e}^{\prime} .1 \mathrm{a}^{\prime \prime}$ unresolved and $4 \mathrm{a}^{\prime}$ orbitals) including $\mathrm{K}_{2} \mathrm{CO}_{3}$ [48,62]. From $640 \mathrm{~K}$ an additional emission showed up at $\sim 5.0 \mathrm{eV}$ which could be attributed to adsorbed oxygen bonded to potassium $\left(\mathrm{K}_{2} \mathrm{O}\right)[56,57]$.

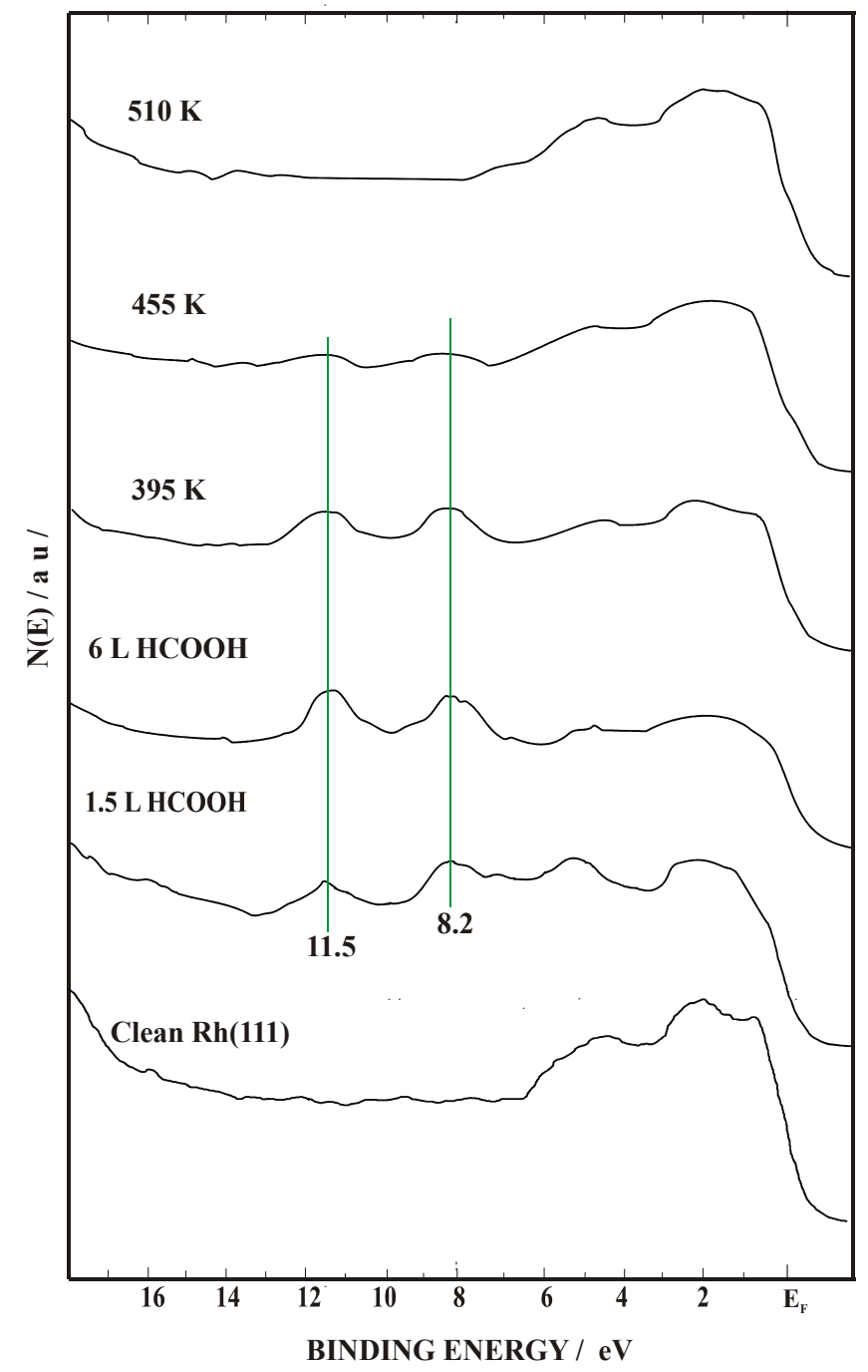

Figure 6. UP spectra after adsorption of FA on clean $\mathrm{Rh}(111)$ at $300 \mathrm{~K}$ and subsequent heat treatment. FA exposure was $12 \mathrm{~L}$. 


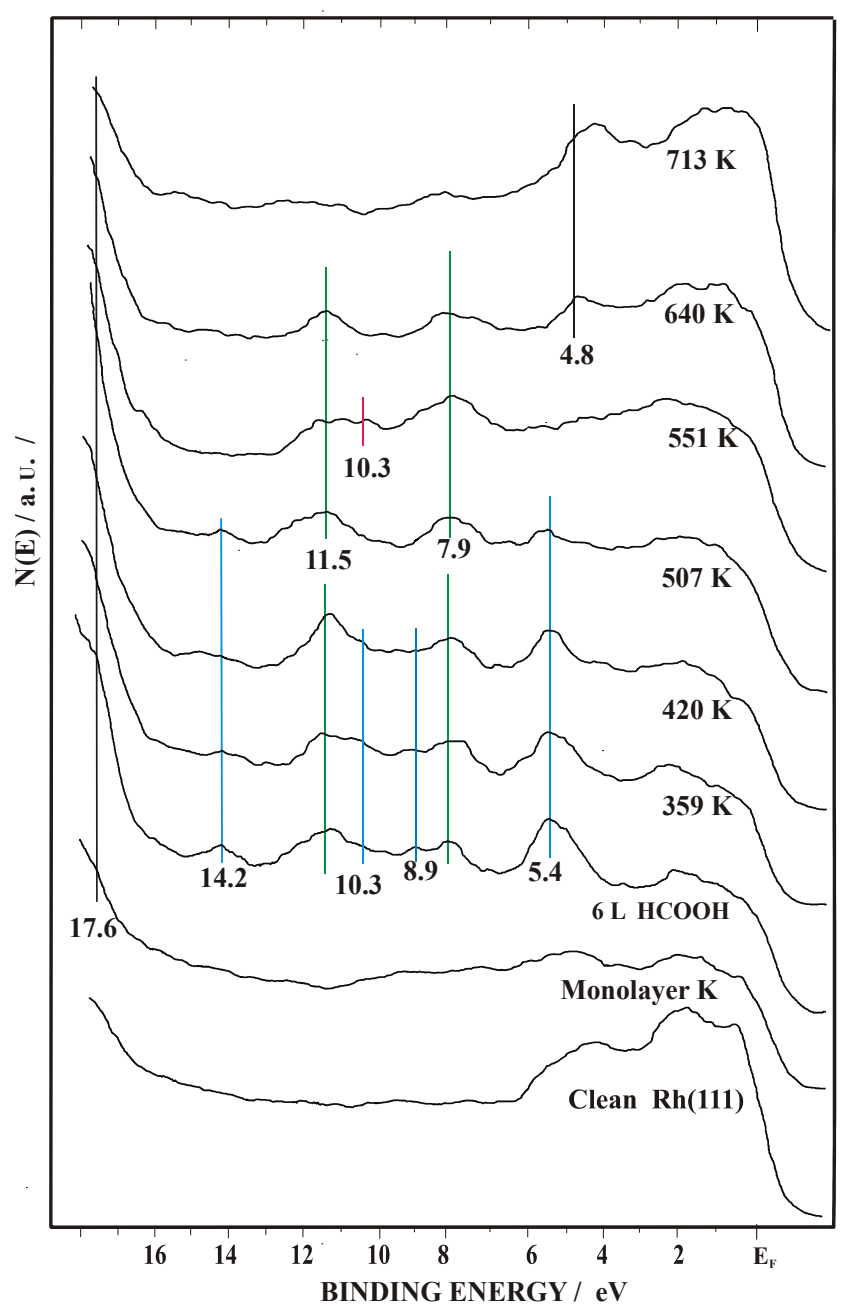

Figure 7. UP spectra after adsorption of FA on potassium covered $\mathrm{Rh}(111)$ at monolayer K coverage, $\Theta_{\mathrm{K}}=0.3$ at $300 \mathrm{~K}$ and subsequent heat treatment. FA exposure was $12 \mathrm{~L}$.

\section{Discussion of Surface Reaction Mechanism}

The study of the decomposition of $\mathrm{HCOOH}$ (FA) and the surface chemistry of formate (HCOO) is receiving increasing attention nowadays. As we demonstrated in the Introduction, the selective decomposition path of FA offers promising channels to access high purity $\mathrm{H}_{2}$ production and FA is a good candidate as a $\mathrm{H}_{2}$ storage compound [2-4]. The classic Sachtler-Fahrenfort volcano curve for $\mathrm{HCOOH}$ decomposition by metal powder catalysts is revisited with application of a modern catalysis approach. The Rh is positioned around the top of the volcano curve [63]. From a catalytic point of view, FA is a very useful precursor molecule in producing formate surface intermediates formed in several catalytic reactions. Formate could be an important intermediate in $\mathrm{CO}_{2}$ methanation [31-34,64]. Formate may also be hydrogenated to methoxy species, which produces methanol [16-20]. Both formate $[37,48,65]$ and methoxide $[66,67]$ can be stabilized by alkali promotors. Rh is one of most investigated metals for $\mathrm{CO}_{2}$ hydrogenation reactions [31,32]. In this, reaction the formate intermediate may decompose to $\mathrm{CO}$, or on the other hand, the formate may be further hydrogenated producing $\mathrm{CH}_{4}$. Moreover, the production of $\mathrm{CO}$ and the methane on supported $\mathrm{Rh}$ catalysts depend upon the temperature, pressure, and presence or absence of promotor. Addition of $\mathrm{Ba}$ and $\mathrm{K}$ to the $\mathrm{Al}_{2} \mathrm{O}_{3}$ support results in significant differences in the catalytic behavior [31,68]. $\mathrm{CH}_{4}$ was preferentially formed on Ba-containing and pure $\mathrm{Rh} / \mathrm{Al}_{2} \mathrm{O}_{3}$ and only $\mathrm{CO}$ was observed with $\mathrm{K}$-containing catalysts.

All these findings motivated us to focus experimentally on the surface chemistry of $\mathrm{HCOOH} /$ formate on Rh without support. The ongoing interest in the surface chemistry of FA 
has also attracted recently extensive density functional theory (DFT) calculations for $\mathrm{HCOOH}$ decomposition on slabs of modified metal surfaces with different facets [69]. Different additives (B, O, alkali metals and $\mathrm{NH}_{4}$ ) significantly alter the decomposition pathway of FA and formate on metal surfaces [35,37-40,42,43,48,70]. Electropositive adatoms (Cs, $\mathrm{K}, \mathrm{NH}_{4}$ ) on metals enhance the extent of dissociation of FA [37-40,48,70]. In the present study, the adsorption and decomposition of FA were studied on potassium-promoted $\mathrm{Rh}(111)$. The adsorption temperature was $300 \mathrm{~K}$. We demonstrated that this adsorption temperature caused a higher dissociation and it altered the product $\left(\mathrm{CO}, \mathrm{CO}_{2}, \mathrm{H}_{2}\right.$ and $\left.\mathrm{H}_{2} \mathrm{O}\right)$ distribution. The promotor effect was significantly higher at $300 \mathrm{~K}$ adsorption then at lower temperature $(100 \mathrm{~K})$. The quantity of the products formed during desorption proportionally increased with potassium coverages, the product distribution was also altered at different potassium concentrations.

The work function $(\Delta \phi)$ increases during the adsorption of FA on $\mathrm{K} / \mathrm{Rh}(111)$ (Figure 5). This suggests a large negative charge on the chemisorbed molecule, which is probably due to the enhanced back-donation of electrons from the potassium-promoted Rh into an empty $\pi$ orbital of $\mathrm{HCOOH}$. We may assume that this enhanced back-donation occurs directly between the formate and the K/Rh surface. The binding energy of the formate species is therefore increased. This would result in a greater concentration of irreversibly adsorbed formate species, and this found in TD studies. At low potassium coverage, where the potassium is of fully ionic character, we suggest to the following steps of formate decomposition from the observed TD spectra:

$$
\begin{gathered}
\mathrm{HCOOH}_{(\mathrm{a})}+\mathrm{K}_{(\mathrm{a})}{ }^{+}=\left\{\mathrm{HCOO}^{-}+\mathrm{K}_{(\mathrm{a})}{ }^{+}\right\}+\mathrm{H}^{+}{ }_{(\mathrm{a})} \\
\left\{\mathrm{HCOO}^{-}+\mathrm{K}_{(\mathrm{a})}{ }^{+}\right\}+\mathrm{H}^{+}{ }_{(\mathrm{a})}=\mathrm{H}_{2(\mathrm{~g})}+\mathrm{CO}_{2}+\mathrm{K}^{+}{ }_{(\mathrm{a})} \\
\left\{\mathrm{HCOO}^{-}+\mathrm{K}_{(\mathrm{a})}{ }^{+}\right\}+\mathrm{H}^{+}{ }_{(\mathrm{a})}=\mathrm{CO}_{\mathrm{g}}+\mathrm{H}_{2} \mathrm{O}_{(\mathrm{g})}+\mathrm{K}^{+}{ }_{(\mathrm{a})}
\end{gathered}
$$

At higher potassium coverages the interpretation of TD spectra is more complex due to the various desorption states. It cannot be excluded that potassium at certain coverages may stabilize the transiently produced $\mathrm{CO}_{2}$ in dimer form. This dimer may disproportionate to carbonate and $\mathrm{CO}$ or releases $\mathrm{CO}_{2}$ with $\mathrm{T}_{\mathrm{p}}=466 \mathrm{~K}$. It is clearly visible at $\Theta_{\mathrm{K}}=0.2$ (Figure $4 \mathrm{~A}$ ). At monolayer $\mathrm{K}$ coverages the interaction of formate and potassium could be stronger, and potassium formate is formed. The first step of decomposition of formate the oxalate formation route in which $\mathrm{H}_{2}$ release below $450 \mathrm{~K}$. In our UP spectra, formate can be detected up to $507 \mathrm{~K}$ (Figure 7). This compound decomposes above $550 \mathrm{~K}$ giving $\mathrm{CO}$ and $\mathrm{CO}_{2}$ desorption with $\mathrm{Tp}=589 \mathrm{~K}$. At the same time $\mathrm{H}_{2} \mathrm{O}$ evolution was also detected. Potassium formate is stable compound [71], its decomposition is described by two parallel occurring reactions via oxalate and carbonate formation according to the literature [71]. It is important to note that carbonate appeared in our UP spectra around $551 \mathrm{~K}$ at 8.4 and $10.3 \mathrm{eV}$ (Figure 7). Accepting these observations, we conclude that the potassium formate decompose similar way on the potassium covered Rh surfaces, too:

$$
\begin{gathered}
2 \mathrm{HCOOK}_{(\mathrm{a})}=\mathrm{K}_{2} \mathrm{C}_{2} \mathrm{O}_{4(\mathrm{a})}+\mathrm{H}_{2(\mathrm{~g})} \\
2 \mathrm{HCOOK}_{(\mathrm{a})}=\mathrm{K}_{2} \mathrm{CO}_{3(\mathrm{a})}+\mathrm{H}_{2} \mathrm{O}_{(\mathrm{g})} \\
\mathrm{K}_{2} \mathrm{C}_{2} \mathrm{O}_{4(\mathrm{a})}=\mathrm{K}_{2} \mathrm{CO}_{3(\mathrm{a})}+\mathrm{CO}_{(\mathrm{g})} \\
\mathrm{K}_{2} \mathrm{CO}_{3(\mathrm{a})}=\mathrm{K}_{2} \mathrm{O}+\mathrm{CO}_{2(\mathrm{~g})}
\end{gathered}
$$

$\mathrm{CO}$ liberates from oxalate-carbonate transformation, the $\mathrm{CO}_{2}$ releases from carbonate decomposition. The $\mathrm{CO}$ and $\mathrm{CO}_{2}$ show up in gas phase at somewhat higher temperature then steps (6) and (7) occur, because the adsorbed potassium may further stabilize them. The highest temperature desorption peak of $\mathrm{CO}_{2}\left(\mathrm{~T}_{\mathrm{p}}=702 \mathrm{~K}\right)$ may also corresponds to $\mathrm{K}_{-} \mathrm{CO}_{2}$ decomposition formed in direct interaction of two species. This feature was found after $\mathrm{CO}_{2}$ adsorption on potassium-covered $\mathrm{Rh}(111)$ and $\mathrm{Pd}(100)$ surfaces [42,52]. The appearance of the photoemission peak at $\sim 5 \mathrm{eV}$ around 
$640 \mathrm{~K}$ may be attributed to the formation of $\mathrm{K}_{2} \mathrm{O}$. The schematically illustration of decomposition of potassium stabilized formate intermediate is displayed in Figure 8.

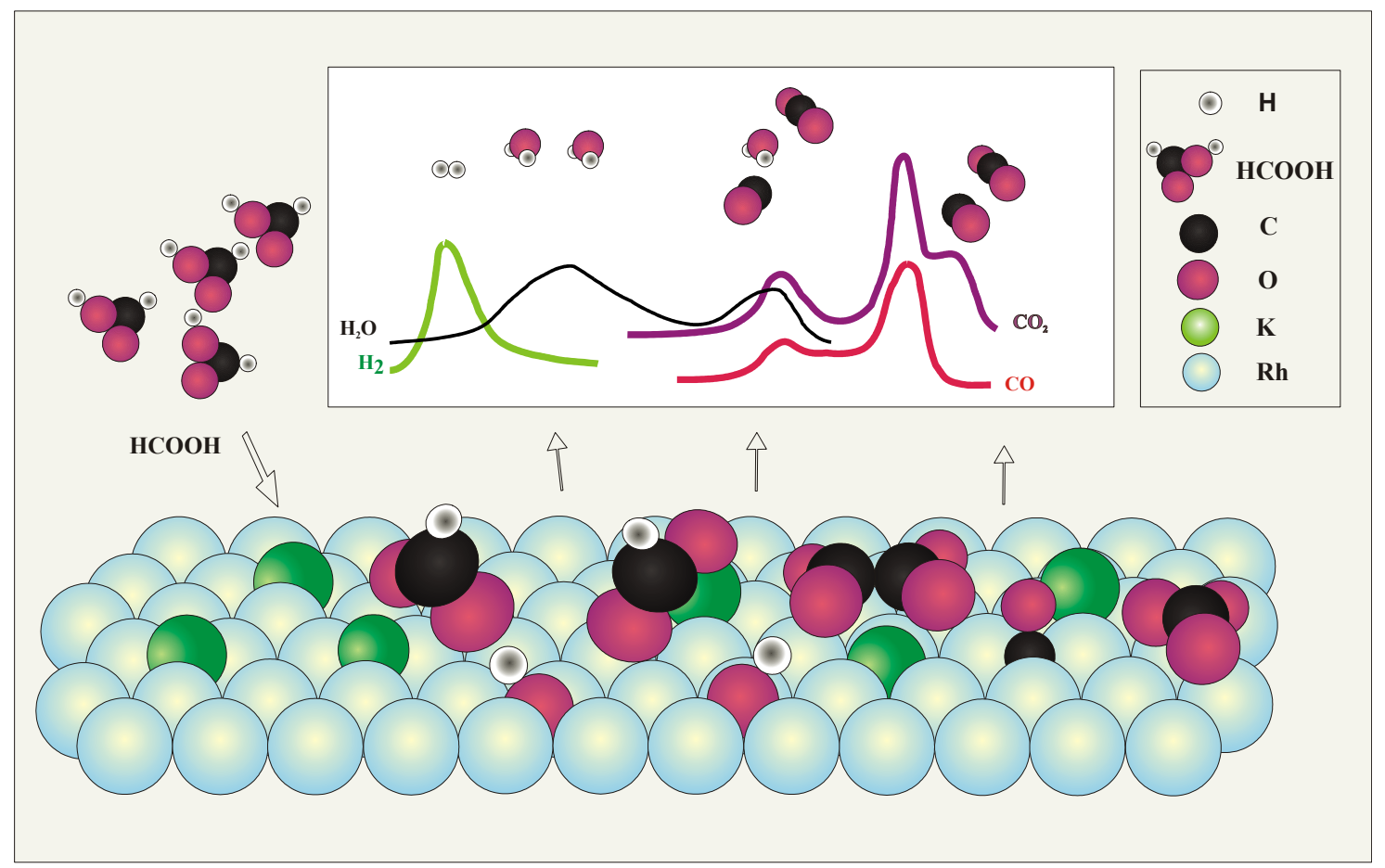

Figure 8. Schematic illustration of formate decomposition on potassium promoted $\mathrm{Rh}(111)$ surfaces.

\section{Experimental}

Experiments were performed in a stainless steel UHV chamber equipped with an electron source for Auger electron spectroscopy (AES), a photon source (He I, He II) for UPS which was pumped differentially, and a quadrupole mass spectrometer for thermal desorption spectroscopy (TDS). An electrostatic hemispherical energy analyzer (LRS 10, Leybold-Hereaus, Cologne, Germany) detected auger and photoelectrons. Changes in work function $((\Delta \phi)$ were obtained from the He I UPS spectra. TDS were taken in "line of sight" with a heating rate of $10 \mathrm{Ks}^{-1}$. The Rh crystal was cut from a single crystal. It was a product of Materials Research Corporation (Orangeburg, Route 303, NY, USA); the purity was $99.99 \%$. The surface orientation was determined by LEED before the present measurements in a separate chamber. The sample was heated resistively, and its temperature was measured by a chromel-alumel thermocouple spot-welded to the edge of the crystal. The cleaning procedure contains argon ion bombardment $\left(600 \mathrm{eV}, 1 \times 10^{-6} \mathrm{mbar} \mathrm{Ar}, 3 \mu \mathrm{A}\right.$ for $\left.10-30 \mathrm{~min}\right)$, and annealing at $1270 \mathrm{~K}$ for some minutes. Contaminations including boron impurity were not detected by AES. A commercial SAES Getter alkali metal source (Lainate, Milan, Italy) was used to deposit K. The K coverage was determined by means of AES and TDS. The determination of $\mathrm{K}$ coverage is described in our previous works $[48,51]$.

\section{Conclusions}

Formic acid (FA) decomposes on clean $\mathrm{Rh}(111)$ at room temperature leaving only $\mathrm{CO}$ on the surface. Potassium adatom basically altered the reaction pathway. Potassium stabilizes the transiently formed formate species. At low potassium coverage $\left(\Theta_{\mathrm{K}}<0.15\right)$, where the $\mathrm{K}$ is fully ionized, a two dimensional $\left\{\mathrm{HCOO}^{-}+\mathrm{K}_{(\mathrm{a})}{ }^{+}\right\}$surface complex is formed, which decomposes to $\mathrm{CO}_{2}, \mathrm{CO}, \mathrm{H}_{2}$ and water. At monolayer potassium coverage $\left(\Theta_{\mathrm{K}} \sim 0.33\right)$, the formate stabilized by potassium transforms into surface compounds (oxalate, carbonate) in consecutive reactions, while $\mathrm{H}_{2}$ and $\mathrm{H}_{2} \mathrm{O}$ are released. Finally $\mathrm{CO}$ and $\mathrm{CO}_{2}$ are liberated from the surface. Potassium was also stabilized by coadsorbates. 
Author Contributions: All authors contributed to write the paper. All authors have read and agreed to the published version of the manuscript.

Funding: This research received no external funding.

Acknowledgments: The authors wish to thank Albert Oszkó for the careful revision of the manuscript. Financial support of this work by the National Research Development and Innovation Office through grant NKFIH OTKA K120115 (Zoltán Kónya).

Conflicts of Interest: The authors declare no conflict of interest.

\section{References}

1. Trillo, J.M.; Munuera, G.; Criado, J.M. Catalytic Decomposition of Formic Acid on Metal Oxides. Catal. Rev. 1972, 7, 51-86. [CrossRef]

2. Yu, Z.; An, X.; Kurnia, I.; Yoshida, A.; Yang, X.; Hao, X.; Abudula, A.; Fang, Y.; Guan, G. Full Spectrum Decomposition of Formic Acid over $\gamma-\mathrm{Mo}_{2} \mathrm{~N}$ Based Catalysts: From Dehydration to Dehydrogenation. ACS Catal. 2020, 10, 5353-5361. [CrossRef]

3. Ding, C.; Shen, T.; Yang, Y.; Xu, X. Involvement of the Unoccupied Site Changes the Kinetic Trend Significantly: A Case Study on Formic Acid Decomposition. ACS Catal. 2020, 10, 5153-5162. [CrossRef]

4. Zhao, L.; Lolli, G.; Wolf, A.; Mleczko, L. Closing the Gap in Formic Acid Reforming. Chem. Eng. Technol. 2018, 41, 1631-1638. [CrossRef]

5. Koós, Á.; Solymosi, F. Production of $\mathrm{CO}-$ Free $\mathrm{H}_{2}$ by Forming Acid Decomposition over $\mathrm{Mo}_{2} \mathrm{C} / \mathrm{Carbon}$ Catalysts. Catal. Lett. 2010, 138, 23-27. [CrossRef]

6. Enthaler, S.; Von Langermann, J.; Schmidt, T. Carbon Dioxide and Formic Acid -The Couple for Environmental-Friendly Hydrogen Storage? Energy Environ. 2010, 3, 1207-1217. [CrossRef]

7. Eppinger, J.; Huang, K.-W. Formic Acid as a Hydrogen Energy Carrier. ACS Energy Lett. 2017, 2, $188-195$. [CrossRef]

8. Halasi, G.; Schubert, G.; Solymosi, F. Photodecomposition of formic acid on N-doped and metal-modified $\mathrm{TiO}_{2}$ : Production of CO-free $\mathrm{H}_{2}$. J. Phys. Chem. C 2012, 116, 15396-15405. [CrossRef]

9. Onishi, N.; Kanega, R.; Fujita, E.; Himeda, Y. Carbon Dioxide Hydrogenation and Formic Acid Dehydrogenation Catalyzed by Iridium Complexes Bearing Pyridyl-Pyrzole Ligands: Effect of an Electron-Donating Substituent on the Pyrazole Ring on the Catalytic Activity and Durability. Adv. Synth. Catal. 2019, 361, 289-296. [CrossRef]

10. Ruiz-Gracia, J.R.; Fierro-Gonzales, J.C.; Handy, B.E.; Hinojosa-Reyes, L.; De Haro Del Rio, D.A.; Lucio-Ortiz, C.J.; Valle-Cervantes, S.; Flores-Escamilla, G.A. An In Situ Infrared Study of $\mathrm{CO}_{2} \mathrm{Hydrogenation}$ to Formic Acid by Using Rhodium Supported on Titanate Nanotubes as Catalysts. ChemistrySelect 2019, 4, 4206-4216. [CrossRef]

11. Reichert, J.; Brunner, B.; Jess, A.; Wasserscheide, P.; Albert, J. Biomass Oxidation to Formic Acid Aqueous Media Using Polyoxometalate Catalysts-Boosting FA Selectivity by in-Situ Extraction. Energy Environ. Sci. 2015, 8, 2985-2990. [CrossRef]

12. Li, J.; Ding, D.-J.; Deng, L.; Guo, Q.-X.; Fu, Y. Catalytic Air Oxidation of Biomass-Derived Carbohydrates to Formic Acid. ChemSusChem 2012, 5, 1313-1318. [CrossRef] [PubMed]

13. Kovács, I.; Kiss, J.; Solymosi, F. On the role of adsorbed formate in the oxidation of $C_{1}$ species on clean and modified Pd(100) surfaces. Vacuum 2017, 138, 152-156. [CrossRef]

14. Grenoble, D.C.; Estadt, M.M.; Ollis, D.F. The chemistry and catalysis of the water gas shift reaction:1 The kinetics over supported metal catalysts. J. Catal. 1981, 67, 90-102. [CrossRef]

15. Pal, D.B.; Chand, R.; Upadhyay, S.N.; Mishra, P.K. Performance of water gas shift reaction catalysts: A Review. Renew. Sustain. Energy Rev. 2018, 93, 549-565. [CrossRef]

16. Kienemann, A.; Hindermann, R.; Brault, R.; Idriss, H. Alcohols synthesis from carbon oxides and hydrogen on palladium and rhodium catalysts. Study of active species. Am. Chem. Soc. Div. Petrol. Chem. 1986, 31, $46-53$.

17. Ud Din, I.; Shaharun, M.S.; Alotaibi, M.A.; Alharthi, A.I.; Naeem, A. Recent developments of heterogeneous catalytic $\mathrm{CO}_{2}$ reduction to methanol. J. $\mathrm{CO}_{2}$ Util. 2019, 34, 20-33. [CrossRef]

18. Cheng, Z.; Lo, C.S. Mechanistic and microkinetic analysis of $\mathrm{CO}_{2}$ hydrogenation on ceria. Phys. Chem. Chem. Phys. 2016, 18, 7987-7996. [CrossRef] 
19. Kiss, J.; Kukovecz, Á.; Kónya, Z. Beyond Nanoparticles: The Role of Sub-nanosized Metal Species in Heterogeneous Catalysis. Catal. Lett. 2019, 149, 1441-1454. [CrossRef]

20. Gui-López, R.; Mota, N.; Llorente, J.; Millan, E.; Pawelec, B.; Fierro, J.L.G.; Navarro, R.M. Methanol Synthesis from $\mathrm{CO}_{2}$ : A Review of Latest Developments in Heterogeneous Catalysis. Materials 2019, 12, 3902. [CrossRef]

21. Solymosi, F.; Tombácz, I.; Kocsis, M. Hydrogenation of CO on supported Rh catalyst. J. Catal. 1982, 75, 78-93. [CrossRef]

22. Falbo, L.; Visconti, C.G.; Lietti, L.; Szanyi, J. The effect of $\mathrm{CO}$ and $\mathrm{CO}_{2}$ methanation over $\mathrm{Ru} / \mathrm{Al}_{2} \mathrm{O}_{3}$ catalysts: A combined steady state reactivity and transient DRIFT spectroscopy study. Appl. Catal. B Environ. 2019, 256, 11779. [CrossRef]

23. Williams, J.; Boffa, A.B.; Salmeron, M.; Bell, A.T.; Somorjai, G.A. The kinetics of $\mathrm{CO}_{2}$ hydrogenation on a Rh foil promoted by titania overlayer. Catal. Lett. 1991, 9, 415-426. [CrossRef]

24. Solymosi, F.; Erdőhelyi, A.; Bánsági, T. Methanation of $\mathrm{CO}_{2}$ on supported rhodium catalyst. J. Catal. 1981, 68, 371-382. [CrossRef]

25. Henderson, M.A.; Worley, S.D. An infrared study of the hydrogenation of carbon dioxide on supported rhodium catalysts. J. Phys. Chem. 1985, 89, 1417-1423. [CrossRef]

26. Sápi, A.; Halasi, G.; Kiss, J.; Dobó, D.G.; Juhász, K.I.; Kolcsár, V.J.; Matolin, V.; Erdőhelyi, A.; Kukovecz, Á.; Kónya, Z. In-Situ DRIFTS and NAP-XPS Exploration of the Complexity of $\mathrm{CO}_{2}$ Hydrogenation Over Size Controlled Pt Nanoparticles Supported on Mesoporous NiO. J. Phys. Chem. C 2018, 122, 5553-5565.

27. Wang, X.; Shi, H.; Kwak, J.H.; Szanyi, J. Mechanism of $\mathrm{CO}_{2}$ hydrogenation on $\mathrm{Pt} / \mathrm{Al}_{2} \mathrm{O}_{3}$ Catalysts. J. ACS Catal. 2015, 5, 6337-6349. [CrossRef]

28. Wang, X.; Hong, Y.; Shi, H.; Shi, H.; Szanyi, J. Kitetic modelling and transient DRIFTS-MS studies of $\mathrm{CO}_{2}$ methanation over $\mathrm{Ru} / \mathrm{Al}_{2} \mathrm{O}_{3}$ catalysts. J. Catal. 2016, 343, 185-195. [CrossRef]

29. László, B.; Baán, K.; Varga, E.; Oszkó, A.; Erdőhelyi, A.; Kónya, Z.; Kiss, J. Photo-induced reactions in the $\mathrm{CO}_{2}$-methane system on titanate nanotubes modified with $\mathrm{Au}$ and $\mathrm{Rh}$ nanoparticles. Appl. Catal. B Environ. 2016, 199, 473-484. [CrossRef]

30. Kukovecz, Á.; Kordás, K.; Kiss, J.; Kónya, Z. Atomic scale characterization and surface chemistry of metal modified titanate nanotubes and nanowires. Surf. Sci. Rep. 2016, 71, 473-546. [CrossRef]

31. Frontera, P.; Macario, A.; Ferraro, M.; Antonucci, P. Supported Catalysts for $\mathrm{CO}_{2}$ Metanation: A Review. Catalysts 2017, 7, 59. [CrossRef]

32. Erdőhelyi, A. Hydrogenation of Carbon Dioxide on Supported Rh Catalysts. Catalysts 2020, 10, 155. [CrossRef]

33. Varga, G.; Sápi, A.; Varga, T.; Baán, K.; Szenti, I.; Halasi, G.; Mucsi, R.; Óvári, L.; Kiss, J.; Fogarassy, Z.; et al. Ambient pressure $\mathrm{CO}_{2}$ hydrogenation over a cobalt/manganese-oxide nanostructured interface: A combined in situ and ex situ study. J. Catal. 2020, 386, 70-80. [CrossRef]

34. Kiss, J.; Sápi, A.; Tóth, M.; Kukovecz, Á.; Kónya, Z. Rh-Induced Support Transformation and Rh Incorporation in Titanate Structures and Their Influence on Catalytic Activity. Catalysts 2020, 10, 212. [CrossRef]

35. Solymosi, F.; Kiss, J. Interaction of $\mathrm{HCOOH}$ with Rhodium Surface Studied by Auger Electron, Electron Energy Loss and Thermal Desorption Spectroscopy. J. Catal. 1983, 88, 173-180. [CrossRef]

36. Brandt, K.; Steinhausen, M.; Wandelt, K. Catalytic and electro-catalytic oxidation of formic acid on pure and Cu-modified Pd[111]-surface. J. Electroanal. Chem. 2008, 616, 27-37. [CrossRef]

37. Moller, P.M.; Godowski, P.J.; Onsgaard, J. Adsorption and decomposition of formic acid on potassium-modified Cu(110). Vacuum 1999, 54, 31-36. [CrossRef]

38. Toomes, R.L.; King, D.A. Potassium-promoted synthesis of surface formate and reactions of formic acid on Co[1010]. Surf. Sci. 1996, 349, 43-64. [CrossRef]

39. Henn, F.C.; Rodriguez, J.A.; Campbell, C.T. Adsorption and reaction of HCOOH on doped Cu(110): Coadoption with cesium, oxygen and $\mathrm{Cs}_{\mathrm{a}}+\mathrm{O}_{\mathrm{a}}$. Surf. Sci. 1990, 236, 282-312. [CrossRef]

40. Kubo, T.; Minami, N.; Aruga, T.; Takagi, N.; Nishijima, M. Adsorption and Thermal Decomposition of Formic Acid on the Si(100)(2x1)-K Surface. J. Phys. Chem. B 1997, 101, 7007-7011. [CrossRef]

41. Silbaugh, T.L.; Karp, E.M.; Campbell, C.T. Energetics of Formic Acid Conversion to Adsorbed Formates on Pt(111) by Transient Calorimetry. J. Am. Chem. Soc. 2014, 136, 3964-3971. [CrossRef] [PubMed]

42. Yao, Y.; Zaera, F. Adsorption and thermal chemistry of formic acid on clean and oxygen-pedosed $\mathrm{Cu}(110)$ single-crystal surfaces revisited. Surf. Sci. 2016, 646, 3744. [CrossRef] 
43. Solymosi, F.; Kiss, J.; Kovács, I. Adsorption of $\mathrm{HCOOH}$ and its reaction with preadsorbed oxygen. Surf. Sci. 1987, 192, 47-65. [CrossRef]

44. Solymosi, F.; Kiss, J. The Effect of Boron Impurity on the Adsorption and Dissociation of $\mathrm{CO}_{2}$ on $\mathrm{Rh}$ Surfaces. Chem. Phys. Lett. 1984, 110, 639-642. [CrossRef]

45. Kiss, J.; Solymosi, F. Adsorption of $\mathrm{H}_{2} \mathrm{O}$ on Clean and Boron-Contaminated Rh Surface. Surf. Sci. 1986, 177, 191-206. [CrossRef]

46. Kiss, J.; Révész, K.; Solymosi, F. Segregation of Boron and Its Reaction with Oxygen on Rh. Appl. Surf. Sci. 1989, 37, 95-110. [CrossRef]

47. Solymosi, F.; Kiss, J.; Kovács, I. Adsorption and Decomposition of Formic Acid on Clean and Potassium Dosed Rh(111) Surfaces. J. Vac. Sci. Technol. 1987, A5, 1108-1109. [CrossRef]

48. Solymosi, F.; Kiss, J.; Kovács, I. Adsorption and Decomposition of HCOOH on Potassium Promoted Rh(111) Surfaces. J. Phys. Chem. 1988, 92, 796-803. [CrossRef]

49. Solymosi, F.; Bugyi, L. Adsorption and Dissociation of $\mathrm{CO}_{2}$ on a Potassium-promoted $\mathrm{Rh}(111)$ Surface. J. Chem. Soc. Faraday Trans. I 1987, 83, 2015-2033. [CrossRef]

50. Weimer, J.J.; Umbach, E.; Menzel, D. The properties of K and CO + K on Ru(001) I. Adsorption, desorption, and structure. Surf. Sci. 1985, 155, 132-152. [CrossRef]

51. Kiss, J.; Révész, K.; Solymosi, F. Photoelectron Spectroscopy Studies of the Adsorption of $\mathrm{CO}_{2}$ on Potassium-Promoted Rh(111) Surface. Surf. Sci. 1988, 207, 36-54. [CrossRef]

52. Crowell, J.E.; Somorjai, G.A. The Effect of Potassium on the Chemisorption of Carbon Monoxide on the Rh(111) Crystal Face. Appl. Surf. Sci. 1984, 19, 73-91. [CrossRef]

53. Kiskinova, M.; Pirug, G.; Bonzel, H.P. Coadsorption of Potassium and CO on Pt(111). Surf. Sci. 1983, 133, 321-343. [CrossRef]

54. Bonzel, H.P. Alkali-promoted gas adsorption and surface reaction on metals. J. Vac. Sci. Technol. A2 1984, 2, 866-872. [CrossRef]

55. Peebles, D.E.; Peebles, H.C.; White, J.M. Electron spectroscopic study of the interaction of coadsorbed CO and $\mathrm{D}_{2}$ on $\mathrm{Rh}(100)$ at low temperature. Surf. Sci. 1984, 136, 463-487. [CrossRef]

56. Kiss, J.; Klivényi, G.; Révész, K.; Solymosi, F. Photoelectron Spectroscopic Studies on the Dissociation of CO on Potassium-dosed Rh(111) surface. Surf. Sci. 1989, 223, 551-568. [CrossRef]

57. Thiel, P.A. The Interaction of Water with Solid Surface: Fundamental Aspects. Surf. Sci. Rep. 1987, 7, 211-385. [CrossRef]

58. Freund, H.-J.; Roberts, M.W. Surface Chemistry of Carbon Dioxide. Surf. Sci. Rep. 1996, 25, $225-273$. [CrossRef]

59. Solymosi, F.; Berkó, A. Adsorption of $\mathrm{CO}_{2}$ on Clean and Potassium-Covered Pd(100) Surfaces. J. Catal. 1986, 101, 458-472. [CrossRef]

60. Barteau, M.A.; Madix, R.J. A study of the relative brönsted acidities complexes on Ag(110). Surf. Sci. 1982, 120, 262-272. [CrossRef]

61. Sexton, B.A.; Hughes, A.E.; Avery, N.R. A spectroscopic study of the adsorption and reaction of methanol, formaldehyde and formate on clean and oxygenated $\mathrm{Cu}(110)$. Surf. Sci. 1985, 155, 366. [CrossRef]

62. Felter, T.E.; Weinberg, W.H.; Lastushkina, G.Y.; Boronin, A.J.; Zhdan, P.A.; Boreskov, G.K. An XPS and UPS study of the kinetics of carbon monoxide oxidation over Ag(111). Surf. Sci. 1982, 118, 369-386. [CrossRef]

63. Tang, Y.; Roberts, C.A.; Perkins, R.T.; Wash, I.E. Revisiting formic acid decomposition on metallic power catalysts: Exploding the HCOOH decomposition volcano curve. Surf. Sci. 2016, 650, 103-110. [CrossRef]

64. Kattel, S.; Yan, B.; Chen, J.G.; Liu, P. $\mathrm{CO}_{2}$ hydrogenation on Pt, $\mathrm{Pt} / \mathrm{SiO}_{2}$ and $\mathrm{Pt} / \mathrm{TiO}_{2}$ : Importance of synergy between Pt and support. J. Catal. 2016, 343, 115-126. [CrossRef]

65. Solymosi, F.; Kovács, I. Adsorption and reaction of HCOOH on K-promoted Pd(100) surfaces. Surf. Sci. 1991, 259, 95-108. [CrossRef]

66. Solymosi, F.; Berkó, A.; Tóth, Z. Adsorption and dissociation of $\mathrm{CH}_{3} \mathrm{OH}$ on clean and K-promoted $\mathrm{Pd}(100)$ surfaces. Surf. Sci. 1993, 285, 197-208. [CrossRef]

67. Raskó, J.; Bontovics, J.; Solymosi, F. FTIR study of the interaction of methanol with clean and potassium-doped $\mathrm{Pd} / \mathrm{SiO}_{2}$. J. Catal. 1994, 146, 22-33. [CrossRef]

68. Wijapalaa, R.; Yu, F.; Pittman, C.U., Jr.; Mlasna, T.T. K-promoted Mo/Co- and Mo/Ni-catalysised Fischer-Tropsch synthesis of aromatic hydrocarbons with and without a $\mathrm{Cu}$ water gas shift catalysts. Appl. Catal. A Gen. 2014, 480, 93-99. [CrossRef] 
69. Herron, J.A.; Scaranto, J.; Ferrin, P.; Li, S.; Mavrikakis, M. Trends in Formic Acid Decomposition on Model Transition Metal Surfaces: Density Functional Theory study. ACS Catal. 2014, 4, 4434-4445. [CrossRef]

70. Karakurt, B.; Kocak, Y.; Ozensoy, E. Enhancemet of Formic Acid Dehydrogenation Selectivity of Pd(111) Single Crystal Model Catalysts Surface via Brønsted Bases. J. Phys. Chem. 2019, 123, 28777-28788.

71. Meisel, T.; Halmos, Z.; Seybold, K.; Pungor, E. The thermal decomposition of alkali metal formats. J. Thermal. Anal. 1975, 7, 73-80. [CrossRef]

(C) 2020 by the authors. Licensee MDPI, Basel, Switzerland. This article is an open access article distributed under the terms and conditions of the Creative Commons Attribution (CC BY) license (http://creativecommons.org/licenses/by/4.0/). 